\title{
Job Satisfaction and Intrapreneurship: The moderating effect of Personality Trait
}

\author{
Syed Nisar Ahmed, Awaisur Rehman, Muhammad Amjad \\ Department of Business Administration \\ International Islamic University Islamabad \\ Pakistan \\ nisarahmedsyed@yahoo.com, \\ awais.rehman@iiu.edu.pk, \\ mam.meticulous@gmail.com
}

Abstract. The purpose of the study was to examine the relationship of job satisfaction and

Received:

January, 2013

1st Revision:

March, 2013

Accepted:

May, 2013 ship between job satisfaction and intrapreneurship. As job satisfaction of employee is enhanced, the employees' intrapreneural abilities get affected positively. The intensity of this relationship depends upon the role of the moderating variable of the study i.e., openness to experience.

Keywords: Job satisfaction, intrapreneurship and openness to experience

JEL classification: J24, J28

\section{INTRODUCTION}

Job satisfaction has always remained a variable of key interest to all the managers in a global setting. Today almost all managers are of the view that job satisfaction should be given a huge attention because it is an employee's satisfaction with his/her job that drives him/her to form an attitude which is linked to the organizational outcomes (Saari\& Judge, 2004). They believe that job's performance is dependent upon how satisfied their employees are (Shore \& Martin, 1989). Researchers are, therefore, in quest of what specific attitude an employee forms when he/she gets satisfied with the job which leads an organization to perform better.

Because of the changing environment today, every organization must be prepared to cope with the change accordingly i.e., it must look for new behavior and leave the old one in order to survive in the market (Senge, 1990). In order to make it, organizations' focus has been diverted to high volume of innovations and creativities. Thus every organization expects its employees to be having entrepreneurship skills. Due to the diversion of focus of today's organization towards continuous improvement practices (Bhuiyan\&Baghel, 2005), it is very important for them to know what causes an employee to innovate or create something that 
has never been innovated or created before i.e., through a learning model (Buckler, 1996). The main focus of the study is what impact does job satisfaction cause on the employees' entrepreneurial skills.

There have been a reasonable amount of studies on the relationship of job satisfaction and entrepreneurship. Antoncic and Antoncic (2011) examined the relationship between employee satisfaction, entrepreneurship and firm growth and concluded getting employees come up with ideas and development of their satisfaction with the job can increase the growth chances of firms. The study proved the hypothesis that employee satisfaction leads to intrapreneurship in the firm.

The purpose of this study is thus to find the relationship of job satisfaction and openness to experience with intrapreneurship keeping the same personality trait a moderating variable. This study identifies gap in three ways. First this study is different from the study of Antoncic and Antoncic (2011) in terms of unit of analysis. They have studied organizations as a whole whereas the unit of analysis of this study is employee. Secondly according to the current literature there has been no study conducted in which such a model is being studied. Thirdly this study has been conducted in the context of Pakistan where it hasn't been conducted before. Organizations do believe that every individual employee's satisfaction should be assured in order to create a feasible environment for them so that creativity and innovation may be given smooth settings. But is it only the job satisfaction? Does personality play any role in entrepreneurial abilities even if employees are satisfied? This study is intended to answer these questions.

This study would hence help managers to have further explanation on how to get employees satisfied by the application of a model of job satisfaction which leads to develop intrapreneural skills in employees.

\section{LITERATURE REVIEW}

Over the years there have been major studies in the field of Human resource management out of which a large segment of research is devoted to job satisfaction, one of the very important concepts in behavioral sciences. Job satisfaction involves enormous factors behind it. There have been numerous studies on what makes it to satisfy individual employee at work (Millan, Hessels, Thurik, \& Aguado, 2011, D’ Addio, Eriksson \&Frijters, 2003) and what effects would it have when employees are satisfied. In this paper our focus is on the second part of the preceding sentence. The study would thus look for the relationship between Job satisfaction and entrepreneurship keeping personality characteristics as the moderating variable.

\section{INTRAPRENEURSHIP}

Intrapreneurship is the act of behaving like an entrepreneur within corporate settings. Entrepreneur according to oxford dictionary, is defined as, "one who organizes, manages and assumes the risks and reaps the benefits of a new business." Entrepreneurship has remained a topic of key concern to researchers and practitioners due to its valuable importance to an organization (Hult, Snow, Kandemir, 2003 \&Shabbir, 1996). Employees who are entrepreneurs are considered to be precious assets of an organization. This is true because entrepreneurs come up with ideas resulting in creativity or innovation, turning it on for the organization to have a competitive advantage over its competitors. Thus creativity and innovation are considered to be the main components of entrepreneurship (Hill, 2003).

From another dimension, one can also argue that entrepreneurship has increased its importance because of the huge demand of innovations due to the changing environment. In this dynamic environment an organization can only survive if it looks for different innovations and keeps on changing with the changing environment. In this study thus we would examine what impact does job satisfaction have on employeesintrapreneural abilities. 


\section{H1: JOB SATISFACTION AND INTRAPRENEURSHIP ARE POSITIVELY ASSOCIATED.}

\section{Job Satisfaction}

Locke (1976) defines job satisfaction as, "a pleasurable or positive emotional state resulting from the appraisal of one's job or job experience" (p. 1304). It is the extent to which employees like or dislike their jobs. The operationalization of the concept of job satisfaction has received a fair bit of attention. Different researchers have broken job satisfaction down into different elements. Out of which according to Herzerg's (1964, 1966) two factor theory job satisfaction's motivators are achievement, responsibility, the work itself, recognition, advancement and growth. Others break job satisfaction down into elements such as, flexible work arrangements, training and other professional growth opportunities, interesting work, stable and secure work environment etc.

In addition Hessels ${ }^{\mathrm{B}, \mathrm{C}}$ et. al. (2003) divides job satisfaction into two types. One which is related to the type of work and another is in terms of job security. They further add that employees who are self-employed tend to be more satisfied in terms of work than those who are paid employees. They term self-employment as entrepreneurship. Moreover Antoncic and Antoncic (2011) used the Employee satisfaction elements such as, general satisfaction with work, employee relationships, remuneration, benefits and organizational culture, and employee loyalty. Following this study we are going to consider general satisfaction with work, one of the elements of employee satisfaction in our study because our focus is on an individual employee's satisfaction with his job only.

\section{Personality}

Personality is defined as, "a dynamic organization, inside the person, of psychological systems that create the person's characteristic patterns of behavior, thoughts and feelings" G.W. Allport, (1961). Personality has remained the topic of key interest to researchers over many decades. According to Big Five, personality has five distinctive dimensions named and defined as the following:

1. Extraversion: The extent to which employees are sociable, excited, talkative, assertive and highly emotionally expressive.

2. Agreeableness: The extent to which employee possess attributes like trust, altruism, kindness, affection and other personal behaviors.

3. Conscientiousness: The extent to which employees have feature such as high levels of thoughtfulness with good impulse control and goal-directed behaviors.

4. Neuroticism: The extent to which employees experience emotional instability, anxiety, moodiness, irritability and sadness (high neuroticism).

5. Openness to experience: The extent to which employees possess characteristics such as imagination and insights and those who are high in this trait tend to have a broad range of interests.

In this study we are going to take the last dimension of personality Big Five's dimensions namely openness to experience. The reason why openness to experience is taken is because according to, (Yu, 2011) imagination is one of the stages of the model of entrepreneurial state. Thus our hypothesis would be:

\section{H2: OPENNESS TO EXPERIENCE IS POSITIVELY ASSOCIATED WITH INTRAPRENEURSHIP.}

Researchers have tried to study the links between personality and job satisfaction, personality and creativity, personality and other attributes. We here tried to present some of the researcher's findings regarding creativity which is considered to be an important factor towards entrepreneurship, job satisfaction and personality traits. 
Researchers have studied the factors that lead to creativity in organizations. Hon (2011) examined that it is organizational modernity, empowering leadership and supportive coworkers that results in self concordance of employees which further leads to employee creativity. He is of the view self-concordance mediates the relationship between the above variables and creativity which is a one of the important component of intrinsic motivation. In the implications of the study he asserts that managers should focus on the psychological processes of employees in order to make them creative at work.

Along with creativity, risk taking behavior of employees is also very important for organizations in order to drive employees to develop intrapreneural abilities. Wong \&Ladkin (2008) concludes that employee risk taking behavior can be enhanced through intrinsic job-related motivators such as opportunity for advancement and development, loyalty to employees, appreciation and praise of work done, feeling of being involved, sympathetic help with personal problems, and interesting work. He conducted his study on hotel employees.

Some researchers have tried to study the relationship of personality traits and creativity. Nusbaum\& Silvia (2011) contend that openness to experience can be divided into two components i.e., openness and intellect. They conducted their study to find the relationship of openness to experience with creativity and fluid intelligence. They find that the openness component of openness to experience is positively related to creativity but not fluid intelligence whereas the intellect component of openness to experience is positivity related to fluid intelligence but not creativity.

Similarly Harris (2003) measures two dimensions of personality i.e., openness to experience and achievement against intelligence and creativity and finds that both of these dimensions are correlated (small to moderate correlation) with intelligence and creativity. Fink \&Woschnjak (2011) conduct their study on creativity and personality in professional dancers and finds that the dancers who are required to be freely creative on stage showed high levels of creativity both figural and verbal. The researchers are of the view that these modern dancers are found to be more open to experience.

Contrary to the above findings, researchers have also studied the relationship of other traits of personality with creativity. Furnham\&Bachtiar (2008) examine that the correlation of personality with creativity vary as a function of creativity measure. They further adds that among Big five personality traits, extroversion is better predictor of creativity (extroversion is related to the measure of creativity employed in this study).

On the other hand there has also been some studies in which the moderating effect of personality traits is studied with job satisfaction as a variable of the model. Sheykhshabani\&Beshlideh (2011) examine the moderating behavior of three of the personality characteristics namely trait anxiety, anger and conscientiousness on job satisfaction of employees and concluded that the relationship between interpersonal conflict and job satisfaction was moderated by trait anxiety and anger. Moreover the relationship between distributive justice and job satisfaction was moderated by trait anxiety and conscientiousness whereas interpersonal justice and job satisfaction relationship was moderated by trait anxiety.In addition Acuna, Gomez \&Juristo (2008) are of the view that teams with high level of two of the personality traits i.e., agreeableness and conscientiousness have high levels of job satisfaction. Moreover they also conclude that job satisfaction in teams can decrease if conflict takes place among team members.

In additionIlies\& Judge (2002) analyzed the moderating effect of Neuroticism and Extraversion, among Big five on the relationship of mood and job satisfaction. They found that both of the personality traits were related to average level of moods. Taking mood and job satisfaction combined, they found that only Neuroticism explained with-in individual variability in mood and with-in individual variability in job satisfaction. In the above studies all traits of personality except openness to experience have been tested as moderating variables of the study. This study would hence study the impact of openness to experience as a moderating variable too. The hypothesis would also base on the future direction of Antoncic\&Antoncic (2011), in which they mentioned that in the model of employee satisfaction and intrapreneurship, employees personalities 
should be included as a variable in the study. This infers that satisfied employees' personality may increase or decrease the likeliness that they will exhibit intrapreneural behavior in the organization.

\section{H3: OPENNESS TO EXPERIENCE MODERATES THE RELATIONSHIP BETWEEN JOB SATISFACTION AND INTRAPRENEURSHIP.}

\section{METHODOLOGY}

Following the method of convenience sampling, a sample of 115 employees of private sector organizations was selected to collect the primary data for this study. These employees were middle and line managers. Both, self-administered and mailed questionnaire were used. Out of the 115 questionnaires, 95 questionnaires were received back. The response rate was $82.6 \%$. The questionnaire contained a total of 39 items out of which 12 items were for Job satisfaction, 21 items were for intrapreneurship and 6 items were for openness to experience. Job satisfaction items were adopted and adapted from the questionnaire of employee satisfaction used by Antoncic\&Antoncic (2011). Out of the four dimensions of employee satisfaction, the items of general satisfaction with work were selected only, the reason of which is discussed in literature above. Intrapreneurship items were adopted from the thesis of Hill (2003) and the items of openness to experience were adopted from the big five personality traits(Costa \& McCrae, 1992). The reliability values of the scale are shown in the correlation metrics ahead. To test the hypothesis, regression and correlation analysis were used.

Table 1

Demographics

\begin{tabular}{|l|c|c|c|}
\hline \multirow{2}{*}{ Gender } & & Frequency & \%age \\
\hline \multirow{3}{*}{ Age } & Male & 74 & 77.9 \\
\cline { 2 - 4 } & Female & 21 & 21.1 \\
\hline \multirow{4}{*}{ Education } & $20-29$ & 65 & 68.4 \\
\cline { 2 - 4 } & $30-39$ & 27 & 28.4 \\
\cline { 2 - 4 } & $40-49$ & 3 & 3.2 \\
\hline \multirow{3}{*}{ Experience } & Bachelors & 42 & 44.2 \\
\cline { 2 - 4 } & Masters & 43 & 45.3 \\
\cline { 2 - 4 } & M.phil. & 9 & 9.5 \\
\cline { 2 - 4 } & Ph.D. & 1 & 1.1 \\
\cline { 2 - 4 } & $1-4$ & 65 & 68.4 \\
\cline { 2 - 4 } & $5-9$ & 27 & 28.4 \\
\hline
\end{tabular}




\section{RESULTS AND DISCUSSION}

\section{Correlation Analysis:}

The correlation among the three variables namely job satisfaction, intrapreneurship and openness to experience was checked the results of which are reported in the correlation matrix. All the three variables in the study are found to be highly correlated with each other. Throughout the analysis, job satisfaction will be denoted by JS, intrapreneurship will be denoted by INP and openness to experience will be denoted by OTE.

Table 2

Correlation Matrix

\begin{tabular}{|c|c|c|c|c|c|}
\hline & Mean & S.D. & JS & OTE & INP \\
\hline JS & 3.845 & 0.541 & $(0.861)$ & & \\
\hline OTE & 3.971 & 0.589 & $0.595^{* *}$ & $(0.724)$ & \\
\hline INP & 3.874 & 0.367 & $0.503^{*}$ & $0.555^{* *}$ & $(0.760)$ \\
\hline
\end{tabular}

** correlation is significant at 0.01 level of significance

Table 1 shows the correlation matrix. As shown in the table, the mean of job satisfaction is found to be 3.845 where as its standard deviation is found to be 0.541 . The mean of openness to experience is 3.971 with a standard deviation of 0.589 and the intrapreneurship's means is found to be 3.874 and its standard deviation is 0.367 . The correlation values show that job satisfaction is strongly positively correlated to openness to experience and intrapreneurship with the values of 0.595 and 0.503 respectively at the significance level of 0.01. the degree of association between openness to experience and intrapreneurship is found to be 0.555 at the 0.01 significance level which is also positive.

\section{Regression Analysis:}

To test the hypothesis of the study, regression analysis was used in the third step. In order to examine the $\boldsymbol{H} \mathbf{1}$ and $\mathbf{H} \mathbf{2}$ of the study, regression was run keeping job satisfaction and openness to experience as independent and intraprenuership as dependent variable. The results of which are as follows:

Table 3

Regression Analysis

\begin{tabular}{|c|c|c|c|}
\hline Variables & $\mathrm{B}$ & t-stat & Significance \\
\hline$J S$ & $0.181^{*}$ & 2.562 & 0.012 \\
\hline OTE $0.246^{* *}$ & 3.7920 .000 \\
\hline \multicolumn{2}{|l|}{ R square $=35.4 \%$} & Adjusted R square $=34.0 \%$ \\
\hline
\end{tabular}

** correlation is significant at 0.01 level of significance 
The above table reveals that the coefficient of job satisfaction is 0.181 which is positive and highly significant at 0.01 level of significance. The coefficient of openness to experience is also found to be positive and significant $(\beta=0.246$ at sig $=0.000)$. The $t$-stats of Job satisfaction and openness to experience are 2.562 and 3.792 respectively which also show that the result is highly significant. The overall fit of the model is $35.4 \%$ (adjusted R square $=34 \%$ ). Hence job satisfaction and openness to experience are found to be positively associated with intrapreneurship, accepting both $H 1$ and $H 2$.

To test the $H 2$ of the study, moderated regression was used to see the impact of openness to experience on the relationship of job satisfaction and intrapreneurship. Because there was no control variable found, regression analysis was run by entering the job satisfaction in the first step. In the second step, intrapreneurship and openness to experience were entered to see their combined effect whereas interaction term was added in the third step in the model.

Table 4

Moderated Regression Analysis

\begin{tabular}{|c|c|c|c|c|}
\hline Variables & $B$ & Significance & R square & $R$ square change \\
\hline Step 1: & & & & \\
\hline JS & .181 & .012 & \multirow{2}{*}{5} \\
\hline OTE & .246 & .000 & $35.4 \%$ & \multirow{2}{*}{$5.9 \%$} \\
\hline Step 2: & & & & \\
\hline JS $\times$ OTE & 1.994 & .003 & $41.3 \%$ & \\
\hline
\end{tabular}

The results of the model as shown in the table show that when combined effect of job satisfaction, openness to experience were regressed upon job satisfaction along with the interaction term, there was a significant change in $\mathrm{R}$ square. The coefficient of interaction term (job satisfaction $\times$ openness to experience) is 1.994 with the significance level of 0.003 clearly showing it to be significant. The $\mathrm{R}$ square change in the model is reported to be $5.9 \%$. Hence 3, "openness to experience has a moderating effect on the relationship between job satisfaction and intraprenuership", is accepted i.e., openness to experience increases the intensity of the relationship between job satisfaction and intrapreneurship positively.

The findings of this study affirm that job satisfaction is positively associated with intrapreneurship. The more the employees are satisfied with their job, the more are they encouraged to come up with innovative ideas which in accordance the previous studies of (Antoncic\&Antoncic, 2011; Kuratko et. al., 2005) Employees who are satisfied with their jobs tend to be more creative to be intrapreneurs. On the other hand employees who are not satisfied with jobs are less likely to be innovative and creative on their jobs. The study also finds that employees who are highly open to experience tend to be intrapreneurs. This finding is also in accordance with the theory of entrepreneurial state (Yu, 2011) which says that imagination is one of the stages of the model of entrepreneurial state. The study also revealed that openness to experience has significant impact on the intensity of the association between job satisfaction and intrapreneurship meaning that satisfied employees who are highly imaginative, curious, open to new ideas, value emotional experience, and inclined to try new activities are more likely to be intrapreneurs. 
Recommendations and particle implications:

- Following are the recommendations drawn from the results of this study.

- Managers should focus equal and equitable pays structure in their organization so that employees can be rewarded well in comparison to the market.

- Managers should make the work setting a challenging and exciting place for employees so that they can feel sense of accomplishment by fulfilling certain challenging tasks with excitement.

-Managers should place right person in the right place so that employees feel that what they do is the right kind of work that is well in accordance with their aptitude.

- Employees should be allowed to take certain decisions themselves while doing their work. Employees should be asked about what way they think the job should be done. Employees should be flexible enough to decide the best possible way of doing their jobs.

- The performance of the employees should be recognized that is employees should be enforced for showing good behaviors at job so that they can feel prestigious in the organization.

- Employees should be given enough chance of accomplishing a task. They should not be punished on their first mistakes so that they can be encouraged to do well without restricting them from being creative.

- Managers should believe in change as an opportunity rather resisting to change because to remain competitive in the market today, organizations must change with the changing environment.

- Managers should believe in flexible ways of doing things rather than giving employees a prewritten manual of doing things so that employees can be encouraged to come up with innovative and creative ideas at work.

- Managers should get their employees try new things even if something goes wrong in order to get them think freely.

\section{LIMITATIONS AND FUTURE RESEARCH}

This study though carried some limitations with it. One of the major limitations of the study is that the sample size of the study was not large enough. Future research is directed to have a larger sample in order to study such a relationship. Another limitation of the study was the time and resource shortage due to which data was not collected from a diverse set of organization from all fields of life. Future studies should collect data from a much diverse set of organizations. In addition the research was limited to 3 variables only. Future studies should include more variables in this model such as aptitude of the employee, HRM practices such as placement of employees etc. lastly the data was collected from the organizations of Pakistan only, future research should conduct the study in different contexts in order to increase its generalizability to a much wider context.

\section{REFERENCES}

Acuna, S. T.,Gomez, M., \& Juristo, N. (2009), How do personality, team processes and task characteristics relate to job satisfaction and software quality? Information and Software Technology, 51, pp. 627-639.

Allport, G.W. (1961), Pattern and growth in personality, New York: Holt, Rinehard\&Winson.

Costa, P. T., \& McCrae, R. R. (1992), NEO PI-R Professional Manual, Odessa, FL: Psychological Assessment Resources. 
D’ A., Anna C., Eriksson T., \& Frijters (2003), An Analysis of the Determinants of Job Satisfaction when Individuals' Baseline Satisfaction Levels May Differ, Center of Applied Microeconomics, 16.

Fink, A.,\&Woschnjak, S. (2011), Personality and Individual Differences, 51, pp. 754-758.

Furnham, A., \& Bachtiar, V. (2008), Personality and intelligence as predictors of creativity, Personality and Individual Differences, 45, pp. 613-617.

Harris, J. A. (2004), Measured intelligence, achievement, openness to experience, and creativity, Personality and Individual Differences, 36, pp. 913-929.

Hon, A. H.Y. (2001), Enhancing employee creativity in the Chinese context: The mediating role of employee self-concordance, International Journal of Hospitality Management, 30, pp. 375-384.

Hult, G. T. M., Snow, C. C., \& Kandemir, D. (2003), The Role of Entrepreneurship in Building Cultural Competitiveness in Different Organizational Types, Journal of Management, 29(3), pp. 401-426.

Ilies, R. \& Judge, T. A. (2002), Understanding the dynamic relationships among personality, mood, and job satisfaction: A field experiencing sampling study, Organizational Behavior and Human Decision Processes, 89, pp. 1119-1139.

Locke, E.A. (1976), The nature and causes of job satisfaction, In: M.D. Dunnette (Ed.), Handbook of industrial and organizational psychology, pp. 1297-1349.

Millan $^{\mathrm{A}}$, J. M., Hessels ${ }^{\mathrm{B}, \mathrm{C}}$, J., Thurik ${ }^{\mathrm{B}, \mathrm{C}}$, R., \& Aguado $^{\mathrm{A}}$, R. (2011), Determinants of Job Satisfaction across the EU-15: A comparison of Self-Employed and Paid Employees, Tinbergen Institute Discussion paper, 043 (3).

Nusbaum, E. C., \& Silvia, P. J. (2011), Are Openness and intellect distinct aspects of Openness to Experience? A test of the O/I model, Personality and Individual Differences, 51, pp. 571-574.

Saari, L. M., \& Judge, T. A. (2004), Employee Attitudes and Job Satisfaction, Human Resource Management,43(4), pp. 395-407.

Senge, P. (1990), The Art and Practice of Learning Organization, Doubleday/Currency, New York.

Shabbir, A.,\& Gregorio, S. di. (1996), An examination of the relationship between women's personal goals and structural factors influencing their decision to start a business: The case of Pakistan, Journal of Business Venturing, 11, pp. 507-529.

Sheykhshabani, S. H., \& Beshlideh, K. (2011), Interaction of Environment and Personality in Predicting Job satisfaction of Iranian Employees, Procedia Social and Behavioral Sciences, 15, pp. 4089-4092.

Shore, L. M., \& Martin, H. J. (1989), Job satisfaction and organizational commitment in relation to work performance and turnover intentions, Human Relations, 42(7), pp. 625-638.

Yu, T. F. (2001), Towards a theory of the entrepreneurial state, International Journal of Social Economics,28(9), pp. 752765.

Wong, S. C-k., \& Ladkin, A. (2008), Exploring the relationship between employee creativity and job-related motivators in the Hong Kong hotel industry, International Journal of Hospitality Management,27, pp. 426-437. 